\title{
ОКИСНЮВАЛЬНІ ПРОЦЕСИ В ЩУРІВ РІЗНОГО ВІКУ ЗА КОМБІНОВАНОЇ ДІЇ СОЛЕЙ ВАЖКИХ МЕТАЛІВ ТА ФОСФОРОРГАНІЧНИХ ПЕСТИЦИДІВ
}

Вступ. Отруєння солями важких металів, таких, як Плюмбум, Купрум, є небезпечним для здоров'я населення. В організм людини велика частина цих сполук надходить із продуктами харчування, питною водою, атмосорерним повітрям та ін. Свинець, мідь та їх сполуки проявляють кумулятивну, цитотоксичну дію на організм, викликають активацію оксидативного стресу.

Мета дослідження - вивчити коригувальну дію пептиду на окиснювальні процеси у тварин різних вікових періодів, уражених Плюмбуму ацетатом, Купруму сульфратом і гліфосатом у фрормі раундапу.

Методи дослідження. Досліди проводили на лабораторних нелінійних білих щурах-самцях трьох вікових періодів: статевонезрілих (молодих масою 70-90 г і віком 1-3 міс.), статевозрілих (дорослих масою 170-210 г і віком 5-8 міс.), старих (масою 250-300 г і віком 20-24 міс.), яким внутрішньошлунково протягом 30-ти днів вводили водні розчини Плюмбуму ацетату, Купруму сульфрату і гліфосату у фрормі гербіциду раундапу та виконували корекцію порушень вільнорадикального окиснення ліпідів і білків пептидом цистеїл-гістидил-тирозил-гістидил-ізолейцином. Швидкість процесів вільнорадикального окиснення оцінювали за вмістом ТБК-активних продуктів, дієнових кон'югатів та окисномодифрікованих білків (ОМБ ${ }_{370}$ і ОМБ

Результати й обговорення. Досліджено комбіновану дію Плюмбуму ацетату, Купруму сульфрату i глісросату на показники окисної модифрікації білків і ліпідів у щурів різних вікових періодів. Встановлено, що досліджувані ксенобіотики підвищують концентрацію ТБК-активних продуктів, дієнових кон'югатів, окисну модифрікацію білків.

Висновок. Введення Плюмбуму ацетату, Купруму сульфрату і гліфросату у фрормі раундапу викликає в щурів оксидативний стрес, який супроводжується зростанням вмісту продуктів вільнорадикального окиснення ліпідів та білків.

КЛЮЧОВІ СЛОВА: оксидативний стрес; окисна модифікація білків; Плюмбуму ацетат; Купруму сульфат; гліфосат; хронічна дія; щури.

ВСТУП. За умов швидкого розвитку промисловості, транспорту, сільського господарства і введення в експлуатацію дедалі більшої кількості природних ресурсів зростає рівень впливу на здоров'я населення різних чинників: хімічних, фрізичних, біологічних [1].

Серед різних хімічних забруднювачів навколишнього середовища особливу небезпеку становлять метали (до них належать свинець і мідь), що проявляють високу кумулятивну активність. Їх широко використовують у промисловості, вони у великій кількості містяться в повітрі, ґрунті й воді сучасних міст.

Вплив важких металів на організм людини відбувається переважно через шкіру, дихальну та шлунково-кишкову системи. Іони важких металів, особливо зі змінною валентністю, генерують продукти неповного відновлення кисню -

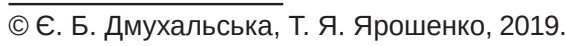

активні фрорми Оксигену, що руйнують біологічно важливі молекули (ліпіди, білки, нуклеїнові кислоти), а також призводять до їх накопичення в клітинах [2]. На молекулярному рівні у срізіологічних концентраціях вільні радикали беруть участь у таких процесах, як передача сигналу в клітині й захист від мікроорганізмів, однак надмірне утворення вільних радикалів або їх недостатня інактивація спричиняє порушення структури клітин та процесів метаболізму, накопичення продуктів окиснення ліпідів і білків $[3,4]$.

Зростання рівня окисної модифрікації білкових молекул є небезпечним процесом, який призводить до інактивації біомолекул і накопичення середньомолекулярних продуктів протеолізу - олігопептидів. Молекули середньої маси за своєю будовою близькі до регуляторних пептидів і здатні сполучатися та блокувати ре- 
цептори будь-якої клітини, неадекватно впливаючи на її метаболізм і фрункції [5].

Не менш токсичними для людини є пестициди. Пестициди (сільськогосподарські отрутохімікати) - хімічні засоби, які використовують для боротьби зі шкідниками і хворобами рослин. Потрапляючи в організм людини, вони викликають порушення функцій серцево-судинної, нервової, видільної систем, шлунково-кишкового тракту та інших органів і систем [6].

Мета дослідження - вивчити коригувальну дію пептиду на окиснювальні процеси у тварин різних вікових періодів, уражених Плюмбуму ацетатом, Купруму сульфратом і гліфосатом у орормі раундапу.

МЕТОДИ ДОСЛІДЖЕННЯ. 3 метою вивчення коригувальної дії пептиду цистеїл-гістидил-тирозил-гістидил-ізолейцину на процеси вільнорадикального окиснення ліпідів і білків за комбінованої дії Плюмбуму ацетату, Купруму сульфату, гліфосату використовували лабораторних нелінійних білих щурів-самців трьох вікових періодів: статевонезрілих (молодих масою 70-90 г і віком 1-3 міс.), статевозрілих (дорослих масою 170210 г і віком 5-8 міс.), старих (масою 250-300 г і віком 20-24 міс.).

Інтоксикацію в щурів викликали шляхом щоденного перорального введення впродовж 30-ти діб водних розчинів Плюмбуму ацетату в дозі 11 мг/кг маси тіла (1/20 LD 50 ), Купруму сульфрату в дозі 13 мг/кг маси тіла (1/20 LD 50 ), гліфросату у формі гербіциду раундапу в дозі 250 мг/кг маси тіла $\left(1 / 20 L_{50}\right)$. 3 метою корекції виявлених порушень на 21-й день експерименту через 6 год після введення токсикантів щодня протягом 10-ти днів вводили внутрішньошлунково пептид цистеїл-гістидил-тирозил-гістидил-ізолейцин у дозі 9 мг/кг маси тіла (концентрація амінокислот у крові). Як контроль використовували інтактних щурів відповідного віку, яким вводили питну водопровідну дехлоровану воду.

Тварин усіх вікових періодів було поділено на такі групи: 1-ша - інтактні (контрольні); 2-га тварини, одночасно уражені всіма вищеперерахованими токсикантами; 3-тя - щури, яким проводили корекцію пептидом. На 31-шу добу після останнього введення ксенобіотиків та чинників корекції тварин виводили з експерименту за умов тіопентал-натрієвого наркозу.

Під час проведення досліджень усі щури перебували у віварії Тернопільського державного медичного університету імені І. Я. Горбачевського на стандартному раціоні відповідно до санітарно-гігієнічних норм. Утримували щурів та проводили всі експерименти на них із дотриманням національних (Закон України № 3447-IV “Про захист тварин від жорстокого поводження", 2006) та міжнародних (Європейська конвенція про захист хребетних тварин, що використовуються для дослідних та інших наукових цілей, Страсбург, 1986) загальних правил і рекомендацій щодо гуманного поводження 3 лабораторними тваринами [7-9].

Стан вільнорадикального окиснення ліпідів оцінювали за вмістом ТБК-активних продуктів (ТБК-АП) і дієнових кон'югатів (ДК) у сироватці крові та гомогенатах печінки [10]. Окисну модифрікацію білків (ОМБ) у сироватці крові досліджували за методом І. Ф. Мещишена [11], який базується на тому, що кінцеві продукти вільнорадикального окиснення білків можуть кількісно реагувати 3 2,4-динітрофренілгідразином 3 утворенням 2,4-динітрофенілгідразонів, які мають характерний спектр поглинання. Альдегідо- і кетонопохідні нейтрального характеру реєстрували при 370 нм $\left(\mathrm{OMБ}_{370}\right)$, а основного - при 430 нм $\left(\mathrm{OMБ}_{430}\right)$.

Статистичну обробку цифрових даних здійснювали за допомогою програмного забезпечення Excel (Microsoft, США) і STATISTICA 6.0 (Statsoft, США) з використанням непараметричних методів оцінки одержаних даних. Для всіх показників розраховували значення середньої арифрметичної вибірки (М), ії дисперсії і помилки середньої (m). Достовірність різниці значень між незалежними кількісними величинами визначали за допомогою критерію Манна - Уїтні. Зміни вважали статистично достовірними при $\mathrm{p}<0,05$ [12].

РЕЗУЛЬТАТИЙ ОБГОВОРЕННЯ. ВіДОМО, ЩО ураження важкими металами та іншими ксенобіотиками супроводжується генерацією активних фрорм Оксигену, пероксидною модифікацією молекул і пригніченням антиоксидантної системи організму, що супроводжується накопиченням активних фрорм Оксигену, продуктів вільнорадикального окиснення ліпідів, білків та ін. [1]. Для оцінки процесів вільнорадикального окиснення ліпідів було визначено рівні ОМБ, ДК і ТБК-АП, якими найчастіше керуються в експерименті та клініці [13].

Результати досліджень (табл. 1-2) показали, що $з$ віком у сироватці крові та гомогенатах печінки інтактних тварин зростав вміст ОМБ, ДК і ТБК-активних продуктів. Такі зміни, очевидно, відображають загальну тенденцію до зниження обміну речовин та накопичення з віком активних фрорм Оксигену.

Дієнові кон'югати є первинними продуктами пероксидного окиснення ліпідів, які утворюються при надмірному вмісті активних фрорм Оксигену, і призводять до деградації клітинних мембран 
Таблиця 1 - Вміст ТБК-активних продуктів і дієнових кон'югатів у сироватці крові та гомогенатах печінки щурів за умов тривалої комбінованої дії Плюмбуму ацетату, Купруму сульфату,

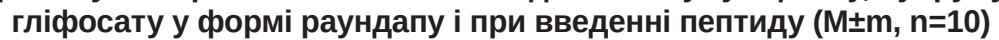

\begin{tabular}{|c|c|c|c|c|}
\hline \multirow[b]{2}{*}{ Група тварин } & \multicolumn{2}{|c|}{ ТБК-активні продукти } & \multicolumn{2}{|c|}{ Дієнові кон'югати } \\
\hline & $\begin{array}{c}\text { сироватка крові, } \\
\text { ммоль/л }\end{array}$ & $\begin{array}{c}\text { гомогенати печінки, } \\
\text { нмоль·мг-1 білка }\end{array}$ & 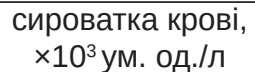 & $\begin{array}{c}\text { гомогенати печінки, } \\
\text { ×103у․ од./кг }\end{array}$ \\
\hline \multicolumn{5}{|c|}{ Статевонезрілі } \\
\hline Інтактні & $6,11 \pm 0,23$ & $37,35 \pm 1,03$ & $1,03 \pm 0,02$ & $5,40 \pm 0,20$ \\
\hline Уражені & $7,18 \pm 0,33^{*}$ & $56,84 \pm 2,36^{*}$ & $1,74 \pm 0,04^{*}$ & $9,77 \pm 0,28$ \\
\hline Кориговані & $6,49 \pm 0,12$ & $38,26 \pm 1,19$ & $1,12 \pm 0,02^{\star *}$ & $5,85 \pm 0,20$ ** \\
\hline \multicolumn{5}{|c|}{ Статевозрілі } \\
\hline Інтактні & $6,43 \pm 0,27$ & $39,05 \pm 1,24$ & $1,11 \pm 0,03$ & $6,24 \pm 0,20$ \\
\hline Уражені & $8,51 \pm 0,18^{*}$ & $56,84 \pm 2,36^{*}$ & $2,11 \pm 0,03^{*}$ & $9,88 \pm 0,58^{\star}$ \\
\hline Кориговані & $6,73 \pm 0,20$ ** & $40,32 \pm 1,17^{\star *}$ & $1,16 \pm 0,04^{\star *}$ & $6,47 \pm 0,27^{\star \star \star}$ \\
\hline \multicolumn{5}{|c|}{ Старі } \\
\hline Інтактні & $6,96 \pm 0,26$ & $42,68 \pm 0,56$ & $1,31 \pm 0,04$ & $7,10 \pm 0,20$ \\
\hline Уражені & $10,75 \pm 0,26^{*}$ & $70,90 \pm 1,15^{\star}$ & $2,91 \pm 0,13^{*}$ & $10,70 \pm 0,14^{\star}$ \\
\hline Кориговані & $7,25 \pm 0,16^{\star \star}$ & $48,07 \pm 0,32^{\star \star}$ & $1,54 \pm 0,32^{\star \star}$ & $7,47 \pm 0,39 \star \star$ \\
\hline
\end{tabular}

Примітка. Тут і в таблиці 2: * - результати достовірні відносно інтактних тварин $(p<0,05)$; ** -результати достовірні відносно показників у щурів при комбінованому ураженні $(\mathrm{p}<0,05)$.

Таблиця 2 - Динаміка вмісту альдегідо- і кетонопохідних нейтрального (ОМБ $\left.{ }_{370}\right)$ й основного (ОМБ ${ }_{430}$ ) характеру в сироватці крові та гомогенатах печінки щурів різного віку за умов комбінованої дії Плюмбуму ацетату, Купруму сульфату, гліфосату у формі раундапу і при введенні пептиду (M $\pm m, \mathrm{n}=10)$

\begin{tabular}{|c|c|c|c|c|}
\hline \multirow[b]{2}{*}{ Група тварин } & \multicolumn{2}{|c|}{$\mathrm{OME}_{370}$} & \multicolumn{2}{|c|}{$\mathrm{OME}_{430}$} \\
\hline & $\begin{array}{c}\text { сироватка крові, } \\
\text { ммоль/л }\end{array}$ & $\begin{array}{c}\text { гомогенати печінки, } \\
\text { моль/кг }\end{array}$ & $\begin{array}{c}\text { сироватка крові, } \\
\text { ммоль/л }\end{array}$ & $\begin{array}{c}\text { гомогенати } \\
\text { печінки, моль/кг }\end{array}$ \\
\hline \multicolumn{5}{|c|}{ Статевонезрілі } \\
\hline Інтактні & $0,65 \pm 0,04$ & $0,81 \pm 0,03$ & $0,52 \pm 0,02$ & $0,57 \pm 0,02$ \\
\hline Уражені & $1,22 \pm 0,05^{\star}$ & $1,13 \pm 0,06^{*}$ & $0,92 \pm 0,03^{*}$ & $1,01 \pm 0,03$ \\
\hline Кориговані & $0,69 \pm 0,05$ & $0,84 \pm 0,02$ & $0,58 \pm 0,02$ & $0,61 \pm 0,02^{\star \star}$ \\
\hline \multicolumn{5}{|c|}{ Статевозрілі } \\
\hline Інтактні & $0,74 \pm 0,05$ & $0,88 \pm 0,03$ & $0,58 \pm 0,02$ & $0,65 \pm 0,02$ \\
\hline Уражені & $1,16 \pm 0,03^{*}$ & $1,52 \pm 0,05$ & $0,90 \pm 0,02^{*}$ & $0,98 \pm 0,04^{*}$ \\
\hline Кориговані & $0,80 \pm 0,04^{\star \star}$ & $0,90 \pm 0,02^{\star \star}$ & $0,61 \pm 0,03$ & $0,68 \pm 0,03^{\star \star}$ \\
\hline \multicolumn{5}{|c|}{ Старі } \\
\hline Інтактні & $0,82 \pm 0,05$ & $0,94 \pm 0,04$ & $0,59 \pm 0,02$ & $0,69 \pm 0,02$ \\
\hline Уражені & $1,44 \pm 0,04^{*}$ & $1,46 \pm 0,09$ & $1,11 \pm 0,03^{*}$ & $1,21 \pm 0,03$ \\
\hline Кориговані & $0,89 \pm 0,06^{\star *}$ & $0,99 \pm 0,32$ & $0,65 \pm 0,03$ & $0,75 \pm 0,03$ \\
\hline
\end{tabular}

$[14,15]$. Результати досліджень вмісту ДК за умов токсичного ураження печінки показали, що він підвищувався за дії ксенобіотиків як у сироватці крові, так і в гомогенатах печінки щурів усіх вікових періодів. Проте найбільшого токсичного впливу зазнавали молоді й старі тварини. Так, за комбінованої дії досліджуваних токсикантів вміст ДК у печінці 3-місячних щурів становив 181 \%, а в 6- і 18-місячних - 158 та 151 \% від норми. У сироватці крові уражених тварин найбільшим він був у старих щурів і в 2,2 раза перевищував норму, тоді як у дорослих зріс в 1,9 раза, а в молодих - в 1,7 раза від рівня інтактних щурів.

Як видно з даних таблиці 1, вміст ТБК-АП у здорових тварин з віком збільшувався. Так, у гомогенатах печінки статевонезрілих щурів він становив $(37,35 \pm 1,03)$ мкмоль/кг і був менший на 4,6 та 14,3 \% порівняно з аналогічним показником у дорослих і старих тварин, а в сироватці крові - $(6,11 \pm 0,23)$ мкмоль/л (на 5,2 та $13,9 \%$ відповідно, $p<0,05)$.

Таким чином, максимальні зміни концентрації як проміжних, так і кінцевих продуктів пероксидного окиснення ліпідів у тварин за поєднаної дії ксенобіотиків спостерігали в статевонезрілих і старих щурів.

За інтоксикації Плюмбуму ацетатом, Купруму сульфатом, гліфосатом зростала концентрація ОМБ як основного, так і нейтрального характеру. Максимальних змін вона зазнала в старих щурів як у гомогенатах печінки, так і в сироватці крові. У сироватці крові ОМБ о $_{370}$ ОМБ $_{430}$ на 76 та $88 \%$ відповідно були вищими від рівня контролю, а в гомогенатах печінки - на 55 і 75 \%. 
Введення ураженим щурам пептиду цистеїлгістидил-тирозил-гістидил-ізолейцину сприяло нормалізації активності вільнорадикальних процесів та відновленню вмісту продуктів окиснення білків і ліпідів, що, очевидно, пов'язано 3 наявністю в коригувального чинника антиоксидантних властивостей. За його дії вміст ТБК-активних продуктів зменшився на $56 \%$.

ВИСНОВКИ. 1. За комбінованої дії досліджуваних токсикантів зростає активність вільнорадикального окиснення в щурів усіх вікових періодів, про що свідчить підвищення вмісту в гомо-

\section{СПИСОК ЛІТЕРАТУРИ}

1. Ahamed M. Environmental lead toxicity and nutritional factors / M. Ahamed, M. K. J. Siddiqui // Clin. Nutr. - 2007. - Vol. 26 (4). - P. 400-408.

2. Effects of subchronic exposure via drinking water to a mixture of eight water contaminating metals: A biochemical and histopathological study in male rats / S. H. Jadhav, S. N. Sarkar, R. D. Patil, H. C. Tripathi // Arch. Environ. Con. Toxicol. - 2007. - 53 (4). - P. 667677.

3. Vaziri N. D. Lead-induced hypertension: Role of oxidative stress / N. D. Vaziri, D. A. Sica // Curr. Hyper. Rep. J. - 2004. - No. 6. - P. 314-320.

4. Neurotoxicity of lead. Hypothetical molecular mechanisms of synaptic function disorders / I. BaranowskaBosiacka, I. Gutowska, M. Rybicka [et al.] // Neurol. Neurochir. Pol. J. - 2012. - 46 (6). - P. 569-578.

5 . Failure of recovery from lead induced hepatoxicity and disruption of erythrocyte antioxidant defence system in wistar rats / T. O. Omobowale, A. A. Oyagbemi, A. S. Akinrinde [et al.] // Environ. Toxicol. Pharm. -2014. No. 37 (3). - P. 1202-1211.

6. Barros R.C.H. Cardiovascular responses to chemoreflex activation with pottassium cyanide or hypoxic hypoxia in awake rats / R. C. Barros, L. G. Bonagamba, R. Okamoto-Canesin [et al.] // Autonomic Neuroscience: Basic, and Clinical. - 2002. - 97. - P. 110-115.

7. Про захист тварин від жорстокого поводження : Закон України від 21.02.2006 р. № 3447-IV.

8. Науково-практичні рекомендації з утримання лабораторних тварин та роботи з ними / Ю. М. Ко- генатах печінки дієнових кон'югатів, ТБК-активних продуктів та окисномодифрікованих білків.

2. Введення ураженим щурам пептиду цистеїл-гістидил-тирозил-гістидил-ізолейцину сприяє зниженню вмісту активних фрорм Оксигену й активності вільнорадикальних процесів. Це вказує на те, що цистеїл-гістидил-тирозил-гістидил-ізолейцин, очевидно, проявляє антиоксидантні властивості.

Перспективи подальших досліджень. Заплановано вивчити коригувальну дію пептидів на порушення білкового обміну в уражених Купруму сульсратом, Плюмбуму ацетатом і раундапом щурів. жем'якін, О. С. Хромов, М. А. Філоненко, Г. А. Сайфетдінова. - К. : Авіцена, 2002. - 156 с.

9. European Convention for the Protection of Vertebrate Animals Used for Experimental and Other Scientific Purposes. - Council of Europe. Strasbourg, 1986. No. 123. -52 p.

10. Камышников В. С. Справочник по клинико-биохимической лабораторной диагностике / В. С. Камышников. - Минск : Беларусь, 2002. - Т. 1. - С. 546-447.

11. Мещишен І. Ф. Метод визначення окиснювальної модифрікації білків плазми (сироватки) крові / І. Ф. Мещишен // Буковин. мед. вісн. - 1998. -2, № 1. C. 156-158.

12. Bernard Rosner. Fundamentals of Biostatistics. Boston, USA. - 2010. - 859 p.

13. Gutteridge J.M. Antioxidants: molecules, medicines and myths / J. M. Gutteridge, B. Halliwell // Biochem. Biophys. Res. Commun. - 2010. - 393. P. 564.

14. Левин Г. Я. Роль перекисного окисления липидов в агрегации клеток крови при ожоговой болезни / Г. Я. Левин, М. Н. Егорихина // Клинич. лаб. диагностика. - 2008. - № 8. - С. 43-44.

15. Shin-Kyo Chung. Hydroxyl radical-scavenging effects of spices and Scavengers from brown mustard (Brassica nigra) / Shin-Kyo Chung, Toshihiko Osawa, Shunro Kawakishi // Biosei. Biotedl. Biochem. - 1997. 61 (1). - P. 118-123. - Access mode : https://doi. org/10.1271/bbb.61.118.

metals: A biochemical and histopathological study in male rats. Arch. Environ. Con.. Toxicol., 53 (4), 667-677.

3. Vaziri, N.D., \& Sica, D.A. (2004). Lead-induced hypertension: Role of oxidative stress. Curr. Hyper. Rep. J., 6, 314-320.

4. Baranowska-Bosiacka, I., Gutowska, I., Rybicka, M., Nowacki, P., \& Chlubek, D. (2012). Neurotoxicity 
of lead. Hypothetical molecular mechanisms of synaptic function disorders. Neurol. Neurochir. Pol. J., 46(6), 569578.

5. Omobowale T.O, Oyagbemi A.A, Olopade, J.O., Saba, A.B., \& Akinrinde, A.S. (2014). Failure of recovery from lead induced hepatoxicity and disruption of erythrocyte antioxidant defence system in wistar rats. Environ. Toxicol. Pharm., 37 (3), 1202-1211.

6. Barros, R.C.H., Bonagamba, L.G.H., \& Machado, B.H. (2002) Cardiovascular responses to chemoreflex activation with pottassium cyanide or hypoxic hypoxia in awake rats. Autonomic Neuroscience: Basic, and Clinical, 97, 110-115.

7. Zakon Ukrainy "Pro zakhyst tvaryn vid zhorstokoho povodzhennia" vid 21.02.2006 r., No 3447 [The Law of Ukraine "On the Protection of animals from ill-treatment" of 02.21. 006, No. 3447]. [in Ukrainian].

8. Kozhemiakin, Yu.M., Khromova, O.S., \& Filonenko, M.A. (2002). Naukovo-praktychni rekomendatsii z utrymannia laboratornykh tvaryn ta robota z nymy [Scientific and practical recommendations for the maintenance of laboratory animals and work with them]. Kyiv: Avitsena [in Ukrainian].

9. (1986). European Convention for the Protection of Vertebrate Animals Used for Experimental and Other Scientific Purposes. Council of Europe. Strasbourg.
10. Kamyshnykov, V.S. (2002). Spravochnyk po kliniko-byokhymycheskoy laboratornoy diagnostike [The manual on clinical and biochemical laboratory diagnostics]. Minsk. 1, 546-447 [in Russian].

11. Meshchyshen, I.F. (1998). Metod vyznachennia okysniuvalnoi modyfikatsii bilkiv plazmy (syrovatky) krovi [Method of determination of oxidizing modification of plasma proteins (serum)]. Bukovyn. med. visn. - Bukovyna Medical Bulletin, 1, 156-158 [in Ukrainian].

12. Bernard Rosner (2010). Fundamentals of Biostatistics. Boston, USA.

13. Gutteridge, J.M., \& Halliwell, B. (2010). Antioxidants: molecules, medicines and myths. Biochem. Biophys. Res. Commun., 393, 564.3.

14. Levin, G.Ya., \& Egorikhina, M.N. (2008). Rol perikesnogo okisleniya lipidov $v$ agregatsii kletok krovi pri ozhogovoy bolezni [Role of lipid peroxidation in aggregation of blood cells in case of burn disease]. Klin. lab. diagnostika - Clinical Laboratory Diagnostics, 8, 4344 [in Russian].

15. Shin-Kyo Chung, Toshihiko Osawa, \& Shunro Kawakishi (1997). Hydroxyl radical-scavenging effects of spices and scavengers from brown mustard (Brassicanigra). Biosei. Biotedl. Biochem., 61 (1), 118123. Retrieved from: https://doi.org/10.1271/bbb.61.118.

\section{ОКИСЛИТЕЛЬНЫЕ ПРОЦЕССЫ У КРЫС РАЗНОГО ВОЗРАСТА ПРИ КОМБИНИРОВАННОМ ДЕЙСТВИИ СОЛЕЙ ТЯЖЕЛЫХ МЕТАЛЛОВ И ФОСФОРОРГАНИЧЕСКИХ ПЕСТИЦИДОВ}

\section{Резюме}

Вступление. Отравление солями тяжелых металлов, таких, как свинец, медь, является опасным для здоровья населения. В организм человека большая часть этих соединений поступает с продуктами питания, питьевой водой, атмосфрерным воздухом и др. Свинец, медь и их соединения проявляют кумулятивное, цитотоксическое действие на организм, вызывают активацию оксидативного стресса.

Цель исследования - изучить корректирующее действие пептида на окислительные процессы у животных разных возрастных периодов, пораженных ацетатом свинца, сульфатом меди и глифосатом в форме раундапа.

Методы исследования. Опыты проводили на лабораторных нелинейных белых крысах-самцах трех возрастных периодов: неполовозрелых (молодых массой 70-90 г и в возрасте 1-3 мес.), половозрелых (взрослых массой 170-210 г и в возрасте 5-8 мес.), старых (массой 250-300 г и в возрасте 20-24 мес.), которым внутрижелудочно в течение 30-ти дней вводили водные растворы ацетата свинца, сульфата меди и глифросата в фрорме гербицида раундапа и выполняли коррекцию нарушений свободнорадикального окисления липидов и белков пептидом цистеил-гистидил-тирозил-гистидил-изолейцином. Скорость процессов свободнорадикального окисления оценивали по содержанию ТБК-активных продуктов, диеновых конъюгатов и окислительномодифицированных белков $\left(О \mathrm{MБ}_{370}\right.$ и ОМБ $\left.{ }_{43}\right)$ в сыворотке крови.

Результаты и обсуждение. Исследовано комбинированное действие ацетата свинца, сульсрата меди и глифосата на показатели окислительной модификации белков и липидов у крыс разных возрастных периодов. Установлено, что исследуемые ксенобиотики повышают концентрацию ТБК-активных продуктов, диеновых конъюгатов, окислительную модификацию белков. 
Вывод. Введение ацетата свинца, сульфрата меди и глифросата в фрорме раундапа вызывает у крыс оксидативный стресс, который сопровождается ростом содержания продуктов свободнорадикального окисления липидов и белков.

КЛЮЧЕВЫЕ СЛОВА: оксидативный стресс; окислительная модификация белков; ацетат свинца; сульфат меди; глифосат; хроническое действие; крысы.

Ye. B. Dmukhalska, T. Ya. Yaroshenko I. HORBACHEVSKY TERNOPIL STATE MEDICAL UNIVERSITY

\section{THE OXIDATION PROCESSES IN DIFFERENT AGE RATS UNDER THE CONDITIONS OF COMPLEX PERSISTENT EFFECT OF HEAVY METAL SALTS AND PHOSPHORORGANIC PESTICIDES}

\section{Summary}

Introduction. Lead poisoning is a major public health risk. Lead is an immunotoxicant, it has reproductive toxicity, liver toxicity. Lead, copper and their compounds exhibit cumulative, cytotoxic effects on the body, cause the activation of oxidative stress.

The aim of the study - to research the correction effect of the peptide on the oxidative processes in different age groups of animals by the lead acetate, the copper sulfate, the glyphosate (in herbicide Roundup) poisoning.

Research Methods. Experiments were performed on lab nonlinear white male rats of three age periods: puberty (young, 70-90 g of body weight and aged 2 to 3 months); mature (adult, weighing 170-210 g and aged 5-8 months) and old rats (body weight 250-300 g and aged 20-24 months), which were injected intragastrically for 30 days with the lead acetate, the copper sulfate, the glyphosate (in herbicide Roundup) and underwent the correction of violations of free radical oxidation of lipids and proteins with peptide cysteyl-histidyl-tyrosyl-histidyl-isoleucine. We studied free radical oxidation processes by the content of TBA-active products (TBA-AP), diene conjugates (DC), and oxidation-modified proteins in blood serum $\left(\mathrm{OMP}_{370}\right.$ and $\left.\mathrm{OMP}_{430}\right)$.

Results and Discussion. The combined effect of lead acetate, copper sulfate and glyphosate on the oxidative modification of proteins and lipids in rats of different age groups was studied. It was established that the studied xenobiotics increase the concentration of TBA-active products, diene conjugates, and oxidative modification of proteins.

Conclusion. It was established that the effect of the lead acetate, the copper sulfate, the glyphosate (in herbicide Roundup) caused oxidative stress in rats, which was accompanied by an increase in the content of free radical oxidation products of lipids and proteins.

KEY WORDS: oxidative stress; oxidation modification of proteins; lead acetate; copper sulfate; glyphosate; chronic effects; rats.

Отримано 26.04.19

Адреса для листування: Є. Б. Дмухальська, Тернопільський державний медичний університет імені І. Я. Горбачевського, майдан Волі, 1, Тернопіль, 46001, Україна, e-mail: dmukhalska@tdmu.edu.ua. 